\title{
FORUM KRITIKA
}

\section{OPPORTUNITY AND ANXIETY IN THE POST-APARTHEID SOCIETY: THE SOUTH AFRICAN NOVEL SINCE 1990 Introduction to Special Forum Kritika}

\section{Peter Horn and Anette Horn University of the Witwatersrand peter.horn@wits.ac.za anette.horn@wits.ac.za}

In 1989, the ANC leaders were released from prison, to be followed by Nelson Mandela in 1990. In her essay "Living in the Interregnum" and in her novel July's People, Nadine Gordimer writes about the interregnum wherein, according to Antonio Gramsci, the old is dying and the new cannot be born. Post-apartheid literature captures the dual sense of opportunity and anxiety entailed in living in our unsettled cities. South Africa's insularity has given way to a proliferation of possibilities. Participants of the anti-colonial or anti-apartheid struggle, exiles and émigrés find their voice as do those who lived through those years in South Africa. In this context the stance of the narrator varies from social witness to anthropological description, dealing with catharsis, sensuality, and the exotic, the spiritual and the mystical, moral instruction, and finally selfjustification.

After February 1990, public life in South Africa was at first dominated by the Truth and Reconciliation Commission and the value it placed on confession. One could think of Foucault's statement that confession is a ritual of discourse that unfolds within a power relationship. There is an "authority who requires the confession" and who judges, punishes, forgives, and consoles. Central in nearly all the novels is the story of the guilt and punishment of the apartheid society. But Coetzee in Disgrace seems to argue against the South African solution of the Truth Commission, which looks too much like the demand of the university disciplinary committee for repentance, which he considers to belong to the discourse of the church and not to the discourse of law.

Zoe Wicomb tests the past of the so-called "coloreds" in the person of Marion who has to confront her own repressed past as a "play white," as a colored who was accepted as white. The woman of her nightmares, Patricia Williams, who was an activist in the anti-apartheid struggle and who was tortured by the police, told her story before the Truth and Reconciliation Commission. Yet the conflated specters of Tokkie and Patricia Williams set off a process whereby Marion finds 
out how the past is imbricated in the present and how - only by facing it - is the fiction of a fixed, unified self broken up, making room for inventions of the future.

Another area of interest would be the ways in which women write women within and/or against both feminist and national discourses; the ways in which women engage the category of "woman" within a fractured and divided polity of South African patriarchies. Besides, South Africa has been seen and portrayed as a site of voyeurism, spiritual regeneration, or sexual adventure.

South African novels portrayed the vision of an anticipated moment of liberation but also stories of personal and political betrayal. In a practical sense, the nation was "rewritten" by the new constitution and, arguably, by the final report of the Truth and Reconciliation Commission and the vast archive of testimony it mustered, rather than by literary works. Concepts of national culture, the state, and citizenship have been redefined in terms of rights, victimhood, and redress. We also need to consider how the struggle years delegitimized a privileging of the aesthetic over the referential, and to look at what J.M. Coetzee has called "the experimental line" within the works of black as well as English and Afrikaans writers, to trace the continuing line of experimentation in post-apartheid literature.

During apartheid, relationships were governed by racist laws, stereotypes, and perceptions rather than intimate conversations or reciprocal interactions. One of the most visible signs of apartheid were the signs which reserved certain spaces for "whites only." There were "whites only beaches" and "whites only park benches" as there were jobs, schools, and universities reserved for whites. There was the fiction that "homelands" were independent countries, and their inhabitants were citizens of these "homelands" and not of South Africa, and that these "foreigners" had to have passports and visas if they wanted to work in the rest of South Africa.

Since 1990 people can move more freely. In much urban theory, there seems to be a consensus that movement through the city and the act of one's moving or walking in city spaces enables one to "remap," redeem, as well as create "new" space. Notably, writings on the city of Johannesburg have tended to acknowledge the need for drastic transformation in the structure of the city, and some have recognized that such transformation is already taking place.This multifaceted, layered, ambiguous nature of not only the city but the country of South Africa in its entirety has gradually begun to be explored by literary critics, theorists, and novelists alike.

Another dominant discourse is the one about the four letter word AIDS, the most feared word in South African society today. Contrary to the initial belief that AIDS was a gay disease, works of fiction and nonfiction depict it as feared by all people-rich, poor, black, white, young and old alike. In South Africa, HIV/AIDS is located mainly among the heterosexual community. But there are also many instances in South Africa where intolerance against gays, and in particular lesbians, has manifested in the form of violent acts such as the notorious "corrective rape" (in which 
lesbians are supposedly "taught a lesson" and forcibly made to acknowledge their roles and place in society) and murder. In such a hostile environment, one may not expect members of the LGBTI community to write personal testimonies documenting their contact with HIV and AIDS, as they would be making themselves vulnerable to attacks since HIV/AIDS carries stigma and shame; homosexuality, on the other hand, is met by societal disapproval on the grounds of immorality and sexual deviancy. Like many AIDS narratives, Beauty's Gift by Sindiwe Magona has created a story revealing silence and denial about AIDS. At the beginning of the novel, silence and denial dominate Beauty's contact with HIV and AIDS. Moele's The Book of the Dead is another type of AIDS writing by a black author and, typical of a novel about AIDS, it deals with the problem of denial and acknowledges the "dreadfulness of the disease."

Another question that arises is which form of literature is most effective in the postapartheid society. In 2004, Michael Chapman identified the short story as the literary form most suited to prevailing conditions in South Africa. At the time, however, short fiction remained for the most part confined to small magazines and journals; multi-author anthologies appeared occasionally, but single-author collections were rare indeed. But now critics believe that the ("modernist") short story "might be particularly suited to our present" insofar as it leaves both "characters and readers on the brink of a recognition that remains ... somewhat inchoate, just out of reach ... this hesitation, this modest authorial purview, seems entirely apt" (Titlestad 190).

Lara Buxbaum shows how Van Niekerkin's Triomf explores this dominance of the visual in encounters with others, and in the process unpacks the "ensemble of practices" which made up the apartheid "scopic regime." Van Niekerk enquires whether looking at the other could potentially facilitate empathy and understanding, or whether this remains merely an act of voyeurism. And that probably remains one of the fundamental issues of the new nation state: are we able to go beyond "watching" each other? Are we able to talk to each other across all the apartheid boundaries? And is the novel one way of encountering the Other beyond the customary stereotypes? 
Chapman, Michael. “A Case of Story: Coetzee, Gordimer, Bosman...!” Current Writing 16.1 (2004): 1-15. Web. 30. Jan. 2012.

Gordimer, Nadine. July's People. New York: Penguin, 1981. Print.

---. "Living in the Interregnum." 1982. The Essential Gesture. Ed. Stephen Clingman. New York: Knopf, 1988. 261-84. Print.

Titlestad, Michael. Afterword. “Observations on Post-Apartheid Literature.” The Mistress's Dog: Short Stories 1996-2010. By David Medalie. Johannesburg: Pan-Macmillan-Picador Africa, 2010. 181-91. Print. 